\title{
Genetic Resistance to Rust of Eucalyptus urophylla Progenies
}

\author{
André Carignato ${ }^{1}$, Cristiano Bueno de Moraes², Léo Zimback ${ }^{3}$, \\ Edson Seizo Mori ${ }^{4}$
}

${ }^{1}$ Departamento de Ciências Agroforestales, Escuela Técnica Superior de Ingeniería, Universidad de Huelva - UHU, Palos de la Frontera/Huelva, Spain

${ }^{2}$ Departamento de Engenharia Florestal, Universidade Federal de Tocantins - UFT, Gurupi/TO, Brazil ${ }^{3}$ Departamento de Defesa Vegetal, Faculdade de Ciências Agronômicas, Universidade Estadual Paulista "Júlio de Mesquita Filho" - UNESP, Botucatu/SP, Brazil

${ }^{4}$ Departamento de Produção e Melhoramento Vegetal, Faculdade de Ciências Agronômicas, Universidade Estadual Paulista "Júlio de Mesquita Filho" - UNESP, Botucatu/SP, Brazil

\begin{abstract}
This study assessed the genetic variability in open-pollinated progenies of Eucalyptus urophylla for resistance to rust (Puccinia psidii). The progeny trial was conducted on a statistical randomized block design with 20 progenies, five plants per plot, and nine replications. Analysis of variance showed high genetic variability for the studied trait, with potential for selection gains. The genetic variability of this population provides support to conduct a breeding program with superior individuals for rust resistance, allowing low costs and minimizing the yield losses on eucalyptus plantations.
\end{abstract}

Keywords: genetic parameters, progeny trial, disease. 
The growth of reforested areas in warmer and wetter regions, the planting of more susceptible species or clonal materials without genetic variation, and the repetitive use of planting areas have created favorable conditions for the occurrence of diseases. Among them, rust caused by the fungus Puccinia psidii, is one of the most limiting diseases to the establishment of new plantations and coppicing of some Eucalyptus species and provenances (Silva et al., 2013).

Native of South America, P. psidii can rapidly spread through asexual reproduction, i.e., uredymospores that are dispersed to other leaves, where they may produce pustules and, consequently, more spores. The development of this disease is favored by periods of rainfall and high humidity, when long periods of leaf wetting promote spore germination and host infection. In Eucalyptus, this fungus can cause reduced growth, destruction of growing shoots leading to leaf malformation, and even death of individuals. These events affect the profitability of forests because of high losses of wood substance, which may reach up to $30 \%$ of the annual increment of reforestation (Furtado et al., 2009).

Several methods have been used to control this disease, such as application of fungicides, harvesting of trees for regrowth in periods unfavorable to rust, and use of resistant plants. The latter is the most advisable method for several reasons, namely, low cost, practicality, and lower environmental impact due to reduced use of fungicides (Zauza et al., 2010).

Therefore, progeny test selection for rust resistance is very important in the continuity of improvement programs for this species. The present study aimed to investigate the genetic variability in open-pollinated Eucalyptus urophylla progenies for resistance to rust caused by the fungus Puccinia psidii.

The field experiment was conducted at the Itatinga Vegetable Garden - USP, municipality of Itatinga, Sao Paulo state, Brazil. The genetic material of E. urophylla used in the study was provided by the Instituto de Pesquisas e Estudos Florestais - IPEF, which is in intermediate phase of the forest improvement program. The open-pollinated progeny trial was installed at $3 \times 2 \mathrm{~m}$ spacing in randomized blocks, with 20 progenies, nine blocks and five plants per plot, totaling 900 plants. This design was chosen with the aim of improving environmental control in view of the lack of uniformity of infection in the field, as well as due to the edaphoclimatic conditions of the study region. A score ranging (Figure 1) adapted from Aparecido et al. (2003) was used to determine the levels of resistance of $E$. urophylla progenies to this fungus at 6 months of age, and the data found were transformed using $\sqrt{x+0.5}$ (Pimentel-Gomes, 1987).

Genetic parameters were estimated using the REML/BLUP procedure in the SELEGEN software (Resende, 2007).

Most of the severity levels analyzed were low and in decreasing order, with approximately $60 \%$ of the progenies tested scoring 0 (immune plants) and approximately $25 \%$ of them scoring 1 (few rust pustules). Percentages of the most severe levels were as follows: $9.89 \%$ of plants scoring 2 and $1.11 \%$ scoring 3 (Figure 2).

Analysis of variance revealed significant values at $5 \%$ probability by the $F$ test for the effect of rust resistance between progenies. These differences showed that there is genetic variability for the trait studied, indicating that this population presents potential for selection gains (Table 1 ).

The experimental coefficient of variation $\left(C V_{\text {exp }}\right)$ for rust resistance, despite data transformations, was $17.21 \%$ (Table 2), but still within normality for Eucalyptus species.

The coefficients of heritability were relatively high for rust resistance of E. urophylla progenies. Average heritability between progenies $\left(h_{m p}^{2}\right)$ was $0.83 ; 0.48$ in individual plants; and 0.44 within progenies. These values are close to those obtained for Eucalyptus grandis progenies evaluated in the field by Silva et al. (2013) and Mori et al. (2004).

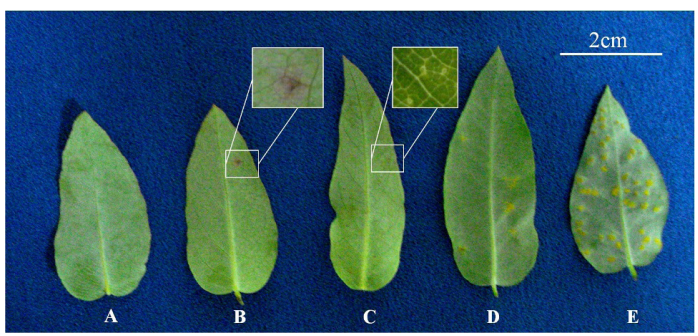

Figure 1. Score ranging used to evaluate the level of resistance to Puccinia psidii in E. urophylla. (A) Immune plants; (B) Hypersensitivity reaction; (C) Lesions without pustules; (D) Lesions with little sporulation; (E) Lesions with highly sporulating pustules. Adapted from Aparecido et al. (2003). 
The additive individual coefficient of genetic variation $\left(\mathrm{CV}_{g i} 25.46 \%\right)$ was greater than the genetic variation between progenies $\left(C V_{g p} 12.73 \%\right)$ for rust resistance. The high value of $C V_{g i}$ shows potential

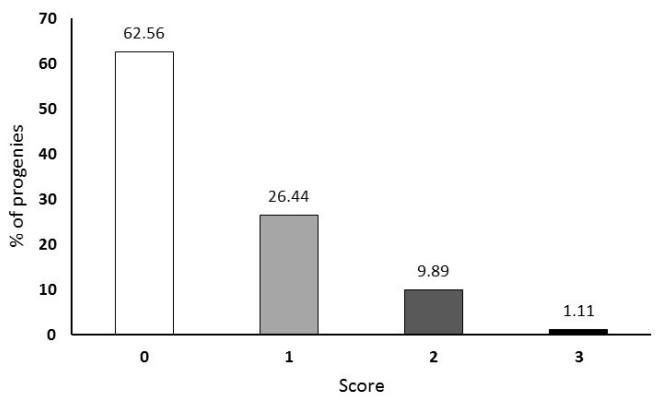

Figure 2. Percentage of severity levels found in the progenies.

Table 1. Analysis of variance for resistance to Puccinia psidii in open-pollinated progenies of Eucalyptus urophylla.

\begin{tabular}{lcccc}
\multicolumn{1}{c}{ FV } & DF & SS & MS & F \\
Fixed effect & 8 & 0.1694 & 0.0212 & $0.7980^{(\mathrm{ns})}$ \\
Progeny & 19 & 2.9894 & 0.1573 & $5.9281^{(*)}$ \\
Residual & 152 & 4.0343 & 0.0265 & - \\
Within & - & - & 0.0994 & - \\
\hline
\end{tabular}

(ns) Not significant at $1 \%$ probability; ${ }^{*}$ Significant at $5 \%$ probability according to the $\mathrm{F}$ test.

Table 2. Estimation of genetic parameters for the rust trait in open-pollinated progenies of Eucalyptus urophylla at 6 months of age under field conditions.

\section{Genetic parameters}

\begin{tabular}{cc}
$h^{2}{ }_{i}$ & $0.4822 \pm 0.1309$ \\
$h^{2}{ }_{a j}$ & 0.5104 \\
$h^{2}{ }_{m p}$ & 0.8313 \\
$h^{2}{ }_{d}$ & 0.4388 \\
$c^{2}{ }_{p a r c}$ & 0.0553 \\
$r_{\text {âa }}$ & 0.9118 \\
$C V_{g i} \%$ & 25.4690 \\
$C V_{g p} \%$ & 12.7340 \\
$C V_{\text {exp }} \%$ & 17.2100 \\
$C V_{r}$ & 0.7400 \\
\hline
\end{tabular}

$h^{2}{ }_{i}=$ narrow-sense individual heritability; $h^{2}{ }_{a j}=$ broad-sense individual heritability; $h_{m p}^{2}=$ average heritability among progenies of half-siblings; $h_{d}{ }_{d}=$ heritability within progenies of half-siblings; $c^{2}$ parc $=$ determination coefficient of plot effects; $r_{\mathrm{âa}}=$ accuracy of progeny selection; $C V_{g i}=$ additive individual coefficient of genetic variation; $C V_{g p}=$ coefficient of genetic variation among progenies; $C V_{\text {exp }}=$ coefficient of experimental variation; $C V_{r}=C V p / C V \exp =$ relative coefficient of variation. for selection in breeding programs. Selection based on genetic values offers practical advantages that range from the design of the experiment to selection, because it enables selection of superior individuals and progenies (Resende \& Higa, 1994).

A medium relative coefficient of variation $\left(C V_{r}\right)$ was found for the trait rust. According to Vencovsky \& Barriga (1992), the higher the $C V_{r}$, the better the genetic control for the trait, favoring the selection process.

High accuracy $\left(\hat{r}_{a a} 91 \%\right)$ was observed in the experiment. According to Resende (1995), the higher is the accuracy, the higher the selection precision. The determination coefficient of plot effects $\left(\mathrm{c}_{\text {parc }}^{2} 5.5 \%\right)$ was low, indicating that the experimental design employed was adequate and provided environmental homogeneity.

The population of E. urophylla analyzed proved to have genetic variability for rust and potential for selection gains and implantation of improved populations, with good individuals and superior progenies. This would enable reduction of expense with rust control and of yield loss in commercial plantations.

\section{ACKNOWLEDGEMENTS}

The authors are grateful to the Estação Experimental de Ciências Florestais de Itatinga for providing space for the experiment and to the Instituto de Pesquisas e Estudos Florestais - IPEF for supplying the genetic material used in the study.

\section{SUBMISSION STATUS}

Received: 1 may, 2014

Accepted: 30 apr., 2017

\section{CORRESPONDENCE TO}

\section{André Carignato}

Departamento de Ciências Agroforestales, Escuela Politécnica Superior, Universidad de Huelva - UHU, Campus Universitario de la Rábida, Carretera Palos de La Frontera, s/n, Postal Code 21819, Palos de La Frontera, Huelva, Spain

e-mail: andrecarignatoflorestal@hotmail.com 


\section{REFERENCES}

Aparecido CC, Figueira MB, Furtado EL. Influência da temperatura sobre a infecção, formação de teliosporos e produção de basidiósporos por Puccinia psidii. Summa Phytopathologica 2003; 29(3): 234-238.

Furtado EL, Dias DC, Ohto CT, Rosa DD. Doenças do Eucalipto no Brasil. 1. ed. Botucatu: Fundação de Estudos e Pesquisas Agrícolas e Florestais; 2009.

Mori ES, Bertoncini G, Zimback L, Mello EJ. Genetic variability of Eucalyptus grandis progenies for rust resistance using quantitative trait and population genetic parameters. In: Proceedings in RAIZ Instituto de Investigação de Floresta e Papel; 2004; Aveiro. Aveiro: RAIZ; 2004. p. 109-115.

Pimentel-Gomes F. Curso de estatística experimental. 12. ed. São Paulo: Nobel; 1987.

Resende MDV, Higa AR. Maximização da eficiência da seleção em testes de progênies de Eucalyptus através da utilização de todos os efeitos do modelo matemático. Boletim de Pesquisas Florestais 1994; 28/29: 37-56.

Resende MDV. Delineamento de experimentos de seleção para maximização da acurácia seletiva e do progresso genético. Revista Árvore 1995; 19(4): 479-500.

Resende MDV. Software Selegen-REML/BLUP. Colombo: Embrapa Florestas; 2007

Silva PHM, Miranda AC, Moraes MLT, Furtado EL, Stape JL, Alvares CA et al. Selecting for rust (Puccinia psidii) resistance in Eucalyptus grandis in São Paulo State. Brazil. Forest Ecology and Management 2013; 303: 91-97. http:// dx.doi.org/10.1016/j.foreco.2013.04.002.

Vencovsky R, Barriga P. Genética biométrica no fitomelhoramento. Ribeirão Preto: Sociedade Brasileira de Genética; 1992. 496 p.

Zauza EAV, Alfenas AC, Old K, Couto MMF, Graça RN, Maffia LA. Myrtaceae species resistance to rust caused by Puccinia psidii. Australasian Plant Pathology 2010; 39(5): 406-411. http://dx.doi.org/10.1071/AP10077. 